\title{
A SOUVENIR FROM NAHUR: A SAMPLE OF "ENTANGLEMENT" IN THE RECONSTRUCTION OF THE Mesopotamian Past
}

\author{
María Dolores Casero Chamorro ${ }^{1}$
}

\begin{abstract}
A.0.76.25 is not a common booty label inscription. The original has yet to be found, but its remembrance is integrated into a larger text, VAT 16381, recorded on a clay tablet, where it is quoted in lines 21 to 24 . The circumstances and context in which this inscription has been transmitted present some peculiarities which make it an excellent example for analysis from the agency theoretical perspective. The study will draw on the model of "entanglement" proposed by Hodder (2012) with regard to the interactions and relations of dependence between the human and object spheres. This will provide a better understanding of looted objects and their role in constructing the Assyrian identity, through their life and the layers of meaning they contained for Adad-nirari I and Tukulti-Ninurta I, the Assyrian kings that possessed them, used them and contemplated them.
\end{abstract}

KEYWORDS: Entanglement theory; cultural memory; Adad-nirari I; Tukulti-Ninurta I; cedar columns.

In the corpus of Assyrian Rulers of the Third and Second Millennium $B C$, Grayson supplies a series of Assyrian royal inscriptions arranged chronologically by kings. The order of the inscriptions within a king's reign is established under typological criteria: groupings of commemorative inscriptions, dedicatory texts, and label texts, all of them translated and enriched with brief commentaries and bibliography. ${ }^{2}$

The section of label inscriptions devoted to the king Adad-nirari I (13071275 BC)3 begins with the royal inscription A.o.76.25, which refers to the king's ownership of the goods inscribed on it and informs of their capture as booty by Adad-nirari I in his north-western expansion. 4

\footnotetext{
${ }^{1}$ Universidad Complutense de Madrid - Consejo Superior de Investigaciones Científicas. Email: md casero@hotmail.com.

${ }^{2}$ Grayson 2002:4.

3 For the chronology and transcription of the royal names I follow Brinkman 1977:335-348.

4 A series of campaigns he undertook to expand the Land of Ashur from the Balikh River up to the left side of the Euphrates, adding thus the land of Hanigalbat, old kingdom of Mitanni (Munn-Rankin 2008:276).
} 
The inscription reads as follows: 5

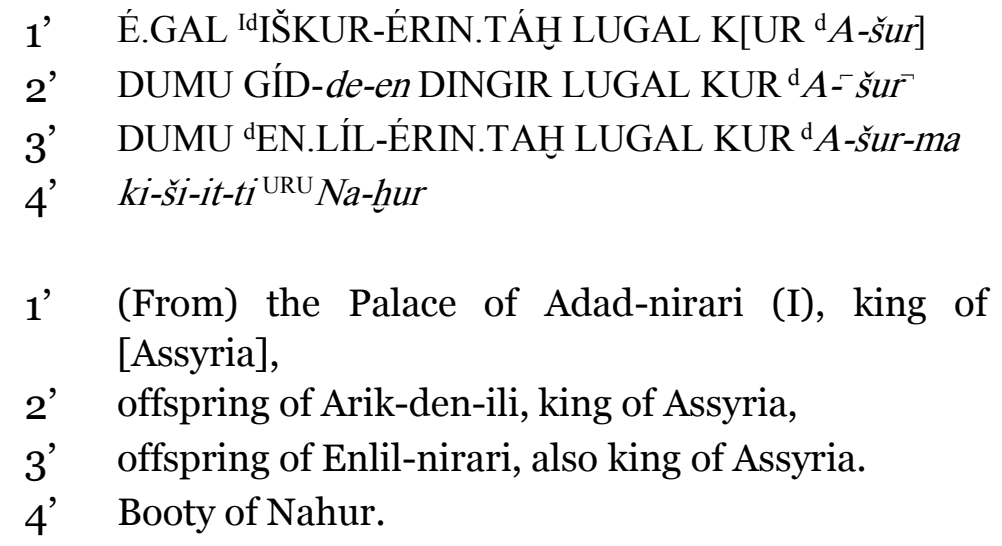

Despite its similarities in content and structure to subsequent label texts, ${ }^{6}$ the unusual circumstances and context in which the inscription has come down to us make it a good case for the application of the model of "entanglement" proposed by Hodder, which concerns the interactions between the human and object spheres and the question of how these deepen our comprehension of the historical past.7

A.0.76.25 is not an ordinary booty label inscription; in fact, it has not reached us in the expected way, namely through the discovery of the booty object where it was inscribed. The original has yet to be discovered, but is nevertheless commemorated and integrated into a larger text, VAT $16381,^{8}$ recorded on a clay tablet where it occupies lines 21 to 24 ( 21 belongs to the obverse and 22-24 to the reverse). ${ }^{9}$ Furthermore, this larger text provides us with a report of the "life-cycle" of the specific loot brought from Nahur: some cedar columns, whose origins, functions, and journeys are being narrated. This

\footnotetext{
5 For a detailed editorial history, see Grayson 2002:159-161. My own translation is based on the reading of Weidner 1954-56, adapted by Grayson 1987.

6 Cf. A.o.76.26, also inscribed on some alabaster vases that were carried off as booty in the north-western expansion, specifically from the great royal city of Taidu (exemplars 2,3,5,6,8,10 of A.0.76.26) and the city of Irridu (exemplar 13 of A.0.76.26), which were conquered in the context of the war against Hanigalbat and narrated in A.0.76.3: 26-27 and A.0.76.3:35, respectively.

7 Hodder 2012. Departing from the materiality approach of archaeology, Hodder engages with the life force inherent in things and humans that makes them agents and actors of historical developments within a dynamic framework of relationships which go beyond the traditional dualist notion of object-subject.

${ }^{8}$ For the abbreviations used in this article check http://cdli.ox.ac.uk/wiki/abbreviations for assyriology.

9 Photo available in http://cdli.ucla.edu/. Catalogue number P282418, drawing in MARV 14 (VS 19).
} 
allows us to construct their "biography" 10 as if they were living beings. The information in the text could be summarized as follows:

In the "palace of Adad-nirari (I)" êkalli Adad-nirari - interpreted as the so-called Old Palace of Ashur (line 21) ${ }^{11}$ - , there was a certain number of cedar columns, presumably 9 or $10,{ }^{12}$ one of which was also apparently coated with bronze or copper (lines 1-2), 13 and whose length ranged from 11 to 7 cubits (lines 3-10).14 The columns were not originally from Ashur, but as the labels on their bases indicate - ina qumašăte ${ }^{15}$-, they were brought from the city of Nahur as booty by Adad-nirari himself (lines 24-25). During the time of Tukulti-Ninurta I (1244-1208 BC), grandson of Adad-nirari I, under whose reign this text was written, ${ }^{16}$ the columns were eventually relocated to a new place in the city, the "Palace of the Tabira-Gate" - ̌sa ina êkallim ša abul Tabira -, the New Palace built by Tukulti-Ninurta ${ }^{17}$ to be part of a shrine - bït papāhiji ${ }^{18}$ (lines 26-27). ${ }^{19}$ After their relocation, we are told that "by royal command" - ina abāt šarri (line 31a)20 - some officials (lines 31b-35a) ${ }^{21}$ were in charge of transporting them from the

10 Gosden and Marshall 1999:69.

${ }^{11}$ Pedde and Lündstrom 2008:159.

12 Weidner 1954-56:146.

13 According to Weidner (ibid.), this could be the interpretation of the first two lines: 1) $1 \mathrm{ti}$-immu ša giš $-r[i-n i]$ 2) ma-su-ú la ga-am-r $[u]$.

14 According to Weidner (ibid.), 3) 11? i-na [am-m] $i-[t]$ e a-ri-ik [...]/ 5) 4 (5?) KI.MINA $10^{\text {ta.àm }}$ i-na am-mi-te [...] 7) 1 KI.MINA 10 i-na am-mi-te a-ri-ik/ 8) 1 KI.MINA 9 i-na am-mi-te a-ri-ik/9) 1 KI.MINA 8 i-na am-mi-te a-ri-ik /10) 1 KI-MINA 7 i-na am-mi-te a-ri-ik. Taking the Assyrian average cubit measure as $50 \mathrm{~cm}$, which would be from 5.5 to $3.5 \mathrm{~m}$. (Powell 1987-90:459).

${ }^{15}$ For the translation of the word qumaštu, see both possibilities contemplated in Weidner 195456:146; CAD Q: 305 remains hesitant to confirm "capital" as correct. I follow the interpretation of Jakob 2003:159 due to the consideration that it is more likely to find this type of inscription at the base of a column than on its capital, which tends to have some other decoration and otherwise less visible. We do find examples of royal inscriptions in cuneiform on column bases from the Achaemenid Empire, such as those of Xerxes in Persepolis and Susa (XPj; XSb cf 114), and Darius II in Susa (D²Sa), to give but a few examples (Lecoq 1997:107, 114 and 115 n3 respectively.)

${ }^{16}$ Thanks to the preservation of the lines 37-38: 37) ITU Qar-ra-a-tu U UV.KÁ[M li-mu]/ 38) IUR.SAG-

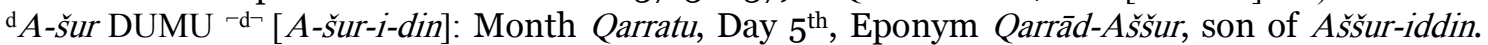
The text can be dated through the Assyrian limmu system to the last decade of TNI, between the $27^{\text {th }}$ and the $3^{\text {th }}$ regnal years, between Ili-pada and Sarniqu, following Bloch PhD. Diss. Unpublished (2012: 157), and Freydank 2009:76.

17 Pedde and Lündstrom 2008:159.

$18 C A D$ P:101 and $A H w: 823$.

19 26) ša i+na É.GAL ${ }^{\text {lim }}$ sa KÁ.GAL ta-bi-ra/ 27) i+na É pa-pa-hi ša-ak-nu-ú-ni “They were placed in the shrine in the palace of the Tabira Gate".

${ }^{20}$ In the day the king performs the offerings of the $5^{\text {th }}$ day from Kar-Tukulti-Ninurta to the

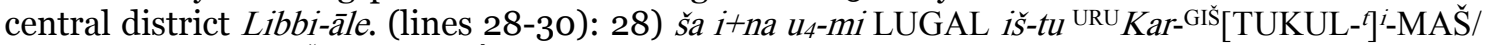

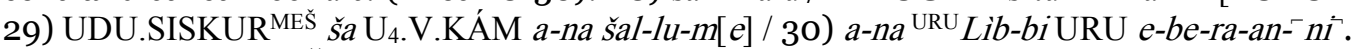

${ }^{21}$ Ilī-ki-abīya, son of Šalim-pî-Ea (= šalimpāju), who had measured them, carried them to Adad-šarnēmeqi, Eunuch of the king ša rēš šarri, as responsible for the transport, and to Ittabši, the city steward ša muhhhi ăle, son of Etirutu, as representative of the local administration (lines31b-34): 31b) IDINGIR-ki-ia-bi-[i]a/ 32) DUMU Ša-lim-pi-i- ${ }^{\mathrm{d}} E$ É a ú-ma-di-[du]-ni / 33) Id IŠKUR-LUGAL-né-me- 
city of Ashur to the new residence of Tukulti-Ninurta I, a palace in the new capital Kār-Tukultī-Ninurta (lines 35b-36).

The story of the tablet starts in the reign of Adad-nirari I, when the conquest of the city of Nahur took place. The event would have been unnoticed, were it not for the record kept in this tablet, since Nahur is mentioned in no other document from his reign.

Adad-nirari I claims to be kašid - conqueror - of the whole territory from the Balikh river up to the left bank of the Euphrates, after crushing the Hanigalbatean revolts of king Šattuara and his successor Wasašatta. ${ }^{22}$ As a natural consequence of his expansion westwards, he emphasises in his most complete speech the conquest of the cities of Amasaku, Kahat, Šuru, Nabula, Hurra, Šuduhu and Waššukanu, Eluhat, Mount Kašiieri, Šudu and Harrānu, ${ }^{23}$ omitting Nahur. He also describes the process of destruction, conquest and plunder of the wealthy goods of its palaces, ${ }^{24}$ and the deportation of its people. ${ }^{25}$

It is thanks to this detailed description that we can assume that a similar dynamic must have been present in the case of the city of Nahur, probably conquered during the same campaign due to its geographical proximity. The city's absence from the lists can be justified by the minor role it must have

qi ša SAG $\ulcorner$ LUGAL $\urcorner$ / 34) ù I It-tab-ši DUMU MíE-KAR-e-te / 35) ša UGU URU a-na URU KarGIŠTUKUL ti_dMAŠ/ 36) ul-te-be-ru (Jakob 2003:159).

22 "When Šattuara, king of the land of Hanigalbat, rebelled against me and committed hostilities [...] after his death Wasašatta, his son revolted, rebelled against me and committed hostilities": 4b) e-nu-ma $\left.{ }^{\mathrm{m}} \breve{s a ́}-a t-t u-a-r[a] / 5\right)$ LUGAL KUR ha-n[i-g]al-bat it-ti-ial 6) ik-ki-ru-ma za-e-[r]u-ti e[p]u-šu [...]15) ar-ki-šu múla-sa-šá-ta DUMU-šu / 16) ib-bal-ki-ta-ma it-ti-ia ik-ki-ir/ 17) ù za-e-ru-ti e-pu-uš (A.0.76.3: 4b- 6 and 15-17 following Grayson 2002:136).

23 (A.0.76.3: 26b-30 and 37-42): "I took by conquest Taidu, his great royal city, the cities of Amasaku, Kahat, Šuru, Nabula, Hurra, Šuduhu and Waššukanu. [...] The great gods gave me to rule from the city Taidu to the city Irridu, Eluhat, Mount Kashiieri, the fortress of the city of Sudu, the fortress of the city Harranu, to the bank of the Euphrates" 26b) URU ta-i-da/ 27) URU LUGAL-ti-šu ra-ba-a URU a-ma-sa-ka/ 28) URU ka-ḩa-at URU šu-ri URU na-bu-la/ 29) URU hu-ur-ra URU šu-du-h̆a/ 30) ù URU uš-šl-ka-na ak-šu-ud aș-bat/ [...] 37) iš-tu URU ta-i-di a-di URU ir-ri-di /38) URU e-lu-ḩa-at ù KUR ka-ši-ie-e-ri / 39) a-di pa-at gi-im-ri-šá / 40) hal-ṣa URU su-da ḩal-ṣa URU har-ra-na/ 41) a-di a-ah ÍD pu-ra-at-ti / 42) DINGIR.MES̆ GAL.MEŚ id-di-nu-ni-ma.

24 (A.0.76.3:31-36): "I took and brought to my city, Ashur, the possessions of those cities, the accumulated (wealth) of his (Wasašatta's) fathers, (and) the treasure of his palace. I conquered, burnt (and) destroyed the city Irridu and sowed salty plants over it." 31) nam-kur URU.DIDLI šatu-nu ni-ki-im-ti / 32) ab-be-šu ni-ṣir-ti É.GAL-li-šu/ 33) al-qa-am-ma a-na URU-ia aš-šur/ 34) ub-la/ 35) URU ir-ri-da ak-šu-ud aš-ru-up/ 36) ‘aq-[qur ù ku-di]-im-me e-li-šu az-ru/.

25 A.0.76.3:46-49a: "I took his sons and daughters and his people. Bound I brought them and his possessions to my city, Ashur”: 46) DUMU.MEŠ-šu DUMU.MUNUS.ME ̌̌s-̌̌u ù um-ma-na-ti-šu/ 47) iš-tu URU ir-ri-di ú-še-și-šu-nu-ti/ 48) ša-lu-su-nu ka-mu-su-nu ù nam-kur-šu/ 49) a-na URU-ia aš-šur $u b$-la. Also mentioned in a couple of administrative texts dated from Shalmanesher I, KAJ 121 (VAT 9016): 6-7 ÉRIN.MEŠ na-ás-hu-te ša URU Na-hur and KAJ 113 (VAT 8997): 26-27 (edited and translated in Postgate 1988:58-59 \&71-72). 
played by those times in the Mitannian kingdom ${ }^{26}$ in comparison with the administrative district capitals of Amasaku or Irridu and the royal seat established in Taidu. By the time of Adad-nirari's successor, Shalmanesher I (1274-1245 BC), the city was certainly integrated into the Assyrian administration, and thus we find it in texts from his reign in which the local governor bēl pāhete from Nahur is mentioned. ${ }^{27}$

However, the richness hidden behind the cedar columns that captured Adad-nirari's attention in Nahur to the point of transporting them to the capital and installing them in his palace is reminiscent of a more glorious past: Nahur's first mention in the records dates from the Sargonic itinerary. ${ }^{28}$ By the time of Zimri-Lim's second regnal year, when it appears as conquered land of Mari, ${ }^{29}$ it had traditionally played an important role in the control of the region of the Idamaraș, located in the northwestern area of the Upper Habur, where it constituted one of the four administrative district centres. ${ }^{30}$ It is also attested as the second station towards Apum on the Old-Assyrian merchant routes on the way to Cappadocia, ${ }^{31}$ a factor which made it an important trading point for goods and materials, and must have facilitated its entrance into the trade circuit of the cedars from Lebanon.

The importance of the columns as reminders of the conquest of the West is thus threefold. Their first and most evident role is that, through their labels, they kept record of the successful expansion of Assyria to the North and West, as has been previously mentioned. Secondly, they served as reminders of the annexation of the weakened Hanigalbat, the former Great Kingdom of Mitanni and member of the "Club of the great powers". ${ }^{2}$ Thirdly, they provided Assyria with the chance to enter this club as the closest substitute.

The booty of Nahur did not consist merely of columns but of a whole formed by many collected layers of meaning. Starting with their physical

\footnotetext{
26 Kupper 1998-2000:86-87.

27 KAJ 109 (VAT 9021):8-9: Melisah, son of Aššur-aha-iddina, governor of Nahur (from Postgate 1988:69).

28 Foster 1992:73.

29 Guichard 2008:46-48.

30 Bryce 2009:494.

${ }^{31}$ Kupper 1982:86.

${ }^{2}$ The four most powerful kingdoms of the Near East by that time: Egypt, Hatti, Babylon and Mittani. They addressed each other as brothers in the international correspondence and dominated international affairs after coming to an agreement of equilibrium among them (Liverani 2001:42).
} 
attributes, the cedar columns were first and foremost columns: columns as architectural devices, "vertical supports, simple wooden posts for instance, that can hold up coverings of shelters (branch huts, tents, etc) and constitute the only solid structural element." 33 In an Assyrian context that was particularly important, since free-standing columns and pillars were never part of the architectural tradition in Mesopotamia. Collon demonstrates that this was mainly due to the lack of appropriate construction materials, since clay and mud-brick in the South and the fibrous date-palm wood or marble in the North were not suitable. 34 Therefore, any development from mud-brick pilasters linked to walls 35 to a genuine architectural tradition of free-standing columns proved unsuccessful..$^{6}$

However, columns as architectural structures were not unknown to the Assyrians. Column and pillar structural elements were part of the Assyrian imagery and experience since the Old-Assyrian trade period of the kārum from Kaniš. The Assyrians encountered foreign architectural practices in the SyrianAnatolian and Syrian-Palestinian regions, in which the column was used from the Neolithic and Chalcolithic times as well as in Bronze Age structures and rooms, such as the so-called bit-hilanni.37 It can be assumed that because of that contact, columns for the Assyrians were from the beginning associated with a western building style.

Moreover, in this particular case, the columns contained another inherent self-reference to their "westerness" through the raw matter they were made of, the cedar - EREN in Sumerian sources, and identified with the gišerēnu in Akkadian ones.38 The acquisition of cedar went beyond the "priorité historique" of the conquest of Mitanni and was rather linked to the "priorite héroique" of the rulers due to two main factors: 39 first, cedars stand out in the Ancient Near Eastern tradition as symbols of the cosmic approach to the "Upper Sea”, the Mediterranean, since they were closely linked with the Mediterranean western lands where they grew along the Lebanon and Amanus ridges; second, they were notorious for the difficulties in access and felling owing to the fact

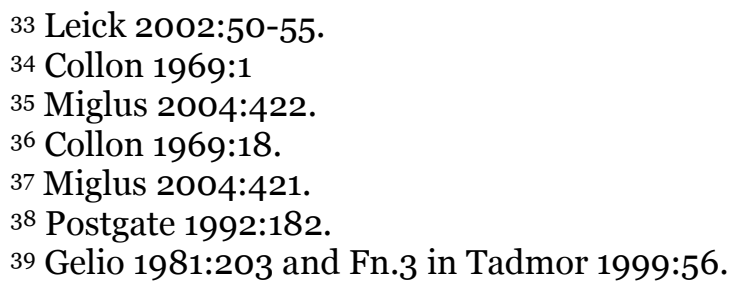


that they grew in some of the highest parts of the mountain slopes, within the range of 1200-2000 meters, with other tall conifers, such as firs and junipers. 40

From a religious perspective, it is worth recalling the "Cedar Forest passage" from the Gilgamesh Epic where the Mountain of Cedar šadû (KUR) giš erēni is interpreted as the place where the gods dwell - mūšab ilī (DINGIR) and the throne-dais of the goddesses is - parak Irnini. ${ }^{41}$ To this should be added that the distinctive aromatic scent produced from its timber was also used as a source of incense for ritual purposes providing close connection to the gods. 42 From a more practical point of view, cedar wood was considered timber of particularly good quality for construction purposes because of its strength and resistance to rot and insects. It possessed a decorative reddish-brown colour, enduring quality, and was easily processed thanks to its close straight grain. 43 All these properties and concepts accompanying the cedar made it a mark of prestige for the Mesopotamian kings since the times of Sargon of Akkad (23002200 BC), 44 adding one more reason for Adad-nirari's attention to the columns.

The unique symbolic and decorative value of the columns is also corroborated by the fact that there was no architectural-cultural transfer process regarding columnar structures in Assyria after that point. The fascination that columns coming from the West caused was not limited to the king Adad-nirari I, assuming that the two exemplars from the Stelenreihen that bear MiddleAssyrian royal names - Nr.15 from Shamshi-Adad IV (1053-50 BC)45 and Nr. 17 Assur-bel-kala (1073-56 BC) ${ }^{46}$ - were brought to Ashur in Middle-Assyrian

\footnotetext{
40 Meiggs 1982:54.

${ }^{41}$ (T V HAA 1-3 \& 6-8) "They stood marvelling at the forest, observing the height of the cedars, observing the way into the forest. [...] They were gazing at the Cedar Mountain, the dwelling of the gods, the throne-dais of the goddesses, [on the] very face of the mountain the cedar was proffering its abundance, sweet was its shade, full of delight.” 1) iz- $z i^{2}-z u-m a i^{-}$- nap ${ }^{-}-p a !-a t^{-}-t u$ gišr qišta (TIR) - 2) šá giš erēni (EREN) it-ta-nap-la-su mi-la-šú/ 3) šá giš qišti (TIR) it-ta-nap-la-sú né-rebšú [...] 6) e e-ma-ru šadû (KUR-ú) gišserēni (EREN) mu-šab ilī (DINGIR.MEŠ) pa-rak dir-ni-ni/ 7) [ina p]a-an šadî (KUR)-im-ma giš erēnu (EREN) na-ši ḩi-șib-šú / 8)[t] a-a-bu șil-la-šú ma-li ri-šá-a-ti (George 2003:602-603).

42 CAD E 1958:276.

43 Moorey 1994:348.

44 Meiggs 1981:72. For Assyria, we rely on the narrative from Šamši-Adad - the first and foremost king of Assyria, when he performed the ritual of washing his weapons in the sea and ascended the Mount Amanus and cut down the cedar trees. This act would be echoed in the late MiddleAssyrian period by Tiglath-pileser I (1114-1078 BC), who legitimised his reign by repeating the heroic deeds of his forefathers, rulers from a more splendorous Assyria. The same act would endure through time and would be recollected once more indeed by Aššurnașirpal II (RIMA 2, 42: 24-30; 218:84-92.) (Tadmor 1999:56).

45 A.0.91.5.

${ }^{46}$ A.0.89.13.
} 
times. 47 As a matter of fact, a more generalised introduction of the columnar architecture will not take place in Assyria until the mid-80os in the NeoAssyrian Late Palaces of Kalhu, Khorsabad, and Nineveh, where the Assyrian kings Tiglath-pileser III (744-727 BC), Sargon II (721-705 BC) and Sennacherib (704-781 BC), and Assurbanipal (668-627 BC) introduced cedar columns with basalt bases as booty from the West as decorative elements for entrance gates and facades. 48

As can be perceived from the relevant lines in VAT 16381, the complexity that underlies the text is represented by a core of "entanglements" that belong to two main spheres: one that belongs to the Human World (H), and another that belongs to the Thing World (T). Both of them not only operate at different levels but also interact with one another. Following Hodder's categorisation, in this 38 -line tablet a web of relationships is revealed according to their grade of dependence:

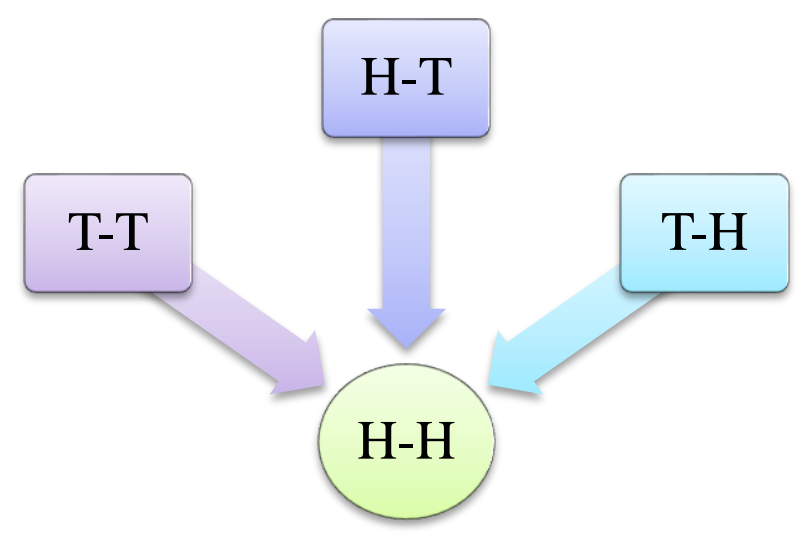

Things' dependence on Things (T-T); Humans' dependence on Things (H-T), Things' dependence on Humans (T-H), and Humans' dependence on Humans $(\mathrm{H}-\mathrm{H})$, which is the interaction process to which the first three are subordinated. Altogether, these dialectical combinations produce the above structural framework based on the new materiality approach, which is

47 Miglus 2004:422-423 contra Porter 2002:81.

48 Collon 1982:17. 
fundamental to the understanding of the Mesopotamian Past,49 since in the end what we are left with to create history is the material heritage preserved.

\section{Co-dependence between Things (T-T)}

I have dealt in this paper with a puzzle of relations of co-dependence between Things, their meanings, and the transmission of memory through a "souvenir" (that is, the cedar columns) within a text, a text within an object, and an object within a text. In order to untangle these relations it would be helpful to picture them as a sort of cube-box game, $5^{\circ}$ where every box becomes at the same time content of a bigger box, and container of smaller one. Thus, the memory of the conquest of Nahur $\left(\mathrm{T}_{1}\right)$ depended on the label-text A.o.76.25 $\left(\mathrm{T}_{2}\right)$, a souvenir within a text; A.o.76.25 as $\mathrm{T}_{2}$ memory box is the text kept within an object, the cedar columns $\left(\mathrm{T}_{3}\right)$. The cedar columns in turn have not come down to us through their material remains, but from reminiscences kept in the box of another text, VAT $16381\left(\mathrm{~T}_{4}\right)$. This makes them object(s) within a text, a text that has become a true example of "a darkly tablet reconstruction", ${ }^{1}$ and that allows us to explore a small part of the Assyrian cultural memory from a broader perspective.

\section{Human reliance on Things (H-T)}

When introducing the human factor to this equation, the dependence relationship H-T is a dual combination which emerges from the fact that Adadnirari I $(\mathrm{H})$ took possession of the cedar columns $(\mathrm{T})$ and recorded labels on them. The act demonstrates the king's personal interest in keeping record, in preserving the memory, of this particular deed in the graven booty, where the label not only represents ownership over the goods stolen, but also over the city and the West itself as a metonym of the part for the whole. It manifests how humans rely on things to create meanings, to justify power and ownership, and achieve eternal glory. 52

\footnotetext{
49 Hodder 2012:211-213.

50 Assmann 2011:101.

51 As the title of the paper by G. Buccellati (1993 Fs. Hallo: 58 ) states, who dealt with the reconstruction of Old Akkadian monuments described in Old Babylonian documents.

$5^{2}$ Hodder 2012:208.
} 


\section{Things' dependence on Humans (T-H)}

The third connection results from another dependence relationship closely linked to the idea of a Thing's agency as "secondary agency" in Gell's terminology.53 The cedar columns (T) become agents, since they are bestowed with the capacity to act over others thanks to the meaning with which the Humans that surrounded them $(\mathrm{H})$ have endowed them, in other words, thanks to the agency that humans assign to them.

The first unknown owner of the columns $(\mathrm{H})$, presumably an important figure from Nahur, ascribed to the columns (T) the status of prestigious artifacts, considering the quality of their material but also their architectural function of supporting some important building structure in the city, likely a palace. When they came to Adad-nirari's hands (H), the columns (T) retained their prestigious agency on account of their material attributes, but their function was altered. They changed from acting as supporting structures to acting as trophies from the West in the eyes of Adad-nirari and the Assyrian public. With the arrival of Tukulti-Ninurta I to power one more layer of meaning was added - though not as a replacement - to the two previous ones.

The intrinsic material value of the columns was preserved, as did the columns' agency as subjects of remembrance of the conquered north-western region, since, after the campaigns of Shalmanesher I, Hanigalbat was integrated into the Assyrian provincial system with its political centre established in DūrKatlimu. By the time of Tukulti-Ninurta, that area was under the control of the Assyrian official that carried the titles of Great Vizier (šukkallu rabiu) and King of Hanigalbat (šar māt Hanigalbat), being fully in charge of its administration.54 It can, therefore, be said that Assyria owned the West in the same manner it owned the cedar columns.

Nonetheless, their status as agents of memories from the West would certainly not have been a sufficient reason for the king Tukulti-Ninurta to transfer them twice, first from the Old Palace to the New Palace in Ashur, and then to his new residence in Kar-Tukulti-Ninurta. These journeys belong to a new agency layer, which reveals that these columns were also now acting as a reminiscence of Tukulti-Ninurta's forefather's policy and acts. A fuller 
understanding of this aspect is enhanced by the conclusions drawn from the meaning of the last entanglement pair: $\mathrm{H}-\mathrm{H}$.

\section{Human co-dependence on Human (H-H)}

The fact that the Assyrian kings developed an early historical consciousness is manifest throughout the written evidence, and from the way they registered the Assyrian royal inscriptions. The Assyrian kings exhibited an obsession with their past and forefathers, whose names were always mentioned after their own as part of a preceding lineage. 55 Furthermore, they also used the inscriptions with the aim of supporting their position as royal inheritors, of guaranteeing their legitimacy in terms of power and government, and at the same time of securing themselves as continuators of the greater plan that the gods had put them in charge of executing: to enlarge Assyria with their right sceptre. 56

This is the key point in interpreting Tukulti-Ninurta's treatment of the cedar columns. Tukulti-Ninurta I was in need of demonstrating that he was not committing any act of defiance against the gods' will, but was rather fulfilling their commands through the innovations promoted by his active building policy in Ashur, 57 as well as through the major development that was the creation of the new eponym capital, Kar-Tukulti-Ninurta. ${ }^{8}$ Tukulti-Ninurta's relationship of power dependence with Adad-nirari turns into one of power dependency through the re-use of the trophy columns of Nahur. Their introduction into his New Palace of the Gate of Tabira in no other place than the chapel, and later into his new capital, was thus a reflection of a tradition anchored in his ancestors past deeds.

Assyrian kings were aware of the cedar-columns' power as Things, and were enchanted by the everlasting life-force 59 of the assemblages they looted.

\footnotetext{
55 Cf. A.0.76.25: 2'-3'.

${ }^{6}$ Casero Chamorro 2014:205.

57 Like the previously mentioned New Palace building in a different location from the Old Palace from his forefathers or the plan change of the Temple of Ishtar (A.0.78.11,12,13,14,15,16).

${ }^{88}$ Separated three kilometers from Ashur, right on the other bank of the Tigris (A.0.78.23; 24; IM57281 and IM76787). The king frequently begins this section with assertions as "My lord requested of me a cult centre and commanded me to build his sanctuary": 90) bēlī (EN) māhāza İrišanni-ma epēš / 91a) atmān̄̄-šu iqbâ (E.g. A.0.78.23:90-91a).

59 Bennet 2010:xvi.
} 
M. D. C. Chamorro. A souvenir from Nahur: "entanglement" and the Mesopotamian Past

These souvenirs from the West became monuments and "remembrance(s) of the things past" in Proust's words. ${ }^{60}$

6o Proust 1982: front cover. 


\section{Bibliography}

Chicago Assyrian Dictionary

"erēnu". In L.A. Oppenheim \& E. Reiner (eds) Chicago Assyrian Dictionary E. 1st edition 1958. Chicago: The Oriental Institute of Chicago, 2004, p.274-279.

"qumāštu". In E. Reiner \& R.D. Biggs (eds) Chicago Assyrian Dictionary Q. 1st edition 1982. Chicago: The Oriental Institute of Chicago, 1995, p.305.

"papāhuu". In M. Roth (ed.) Chicago Assyrian Dictionary P. Chicago: The Oriental Institute of Chicago, 2005, p.101.

Assmann, A. Cultural Memory and Western Civilization, Arts of Memory. Cambridge: Cambridge University Press, 2011.

Bennett, J. Vibrant Matter. A Political Ecology of Things. Durham and London: Duke University Press, 2010.

Bloch, Y. Studies in Middle-Assyrian Chronology and Its Implications for the History of the Ancient Near East in the $13^{\text {th }}$ Century B.C.E. Unpublished Ph.D. Dissertation, Hebrew University of Jerusalem, 2012.

Brinkman, J.A."Appendix: Mesopotamian chronology of the historical Period". In L.A. Oppenheim. Ancient Mesopotamia: Portrait of a Dead Civilization. Chicago: University of Chicago Press, 1977, p.335-348.

Bryce, T. The Routledge Handbook of the Peoples and Places of Ancient Western Asia. The Near East from the Early Bronze Age to the fall of the Persian Empire. Routledge: London and New York, 2009.

Buccellati, G. "Through a tablet darkly. A reconstruction of Old Akkadian monuments described in Old Babylonian copies”. In M. Cohen, D.N. Snell \& D.B. Weisberg (eds) The Tablet and the Scroll. Near Eastern Studies in Honor of William W. Hallo. Bethesda, Maryland: CDL Press, 1993, p.58-71.

Casero Chamorro, M.D. " $Y$ (re)construí el templo desde la cima hasta los cimientos. La política edilicia bajo el reinado de Tukulti-Ninurta I”, AuOr 32(2), 2014, p.195-206.

Collon, D. "Mesopotamian Columns", JANES 2, 1969, p.1-18.

Feldman, M. "Knowledge as cultural biography: Lives of Mesopotamian monuments". In E. Cropper (ed.) Dialogues in Art History, from Mesopotamia to Modern: Readings for a New Century. New Haven and London: Yale University Press, 2009, p.41-55.

Foster, B. "A Sargonic itinerary". In D. Charpin \& F. Joannes (eds) Le Circulation des Biens, des Personnes et des Idées dans le Proch-Orient Ancien, XXVIIIe RAI 1991. Paris: Editions Recherche sur les Civilisations, 1992, p.73-76.

Freydank, H. "Kār-Tukultī-Ninurta als Agrarprovinz", $A o F$ 36, 2009, p.16-84.

Gell, A. Art and Agency: An Anthropological Theory. Oxford: Clarendon Press, 1998. 
George, A. The Babylonian Gilgamesh Epic. Introduction, Critical Edition, Cuneiform Texts V1. Oxford: Oxford University Press, 2003.

Gosden, C., Marshall, Y. "The cultural biography of objects”, WA 31(2), 1999, p.169-178.

Grayson, A.K. Assyrian Rulers of the Third and Second Millennia BC (to 1115 $B C)$. 1st edition 1987. Toronto-Buffalo-London: University of Toronto Press, 2002.

Assyrian Rulers of the Early First Millennium BC I (1114-859 BC). 1st edition 1991. Toronto-Buffalo-London: University of Toronto Press, 2002 (1991).

Guichard, M. "Nahur et la route des marchands assyriens à l'époque de ZimrîLîm”. In J. Drecksen (ed.) Anatolia and the Jazira during the Old-Assyrian Period. Leiden: NINO, 2008, p.43-53.

Hodder, I. Entangled Archaeology. An Archaeology of Relationships between Humans and Things. Chichester: Wiley-Blackwell, 2012.

Jakob, S.Mittelassyrische Verwaltung und Sozialstruktur. CM 29. Leiden and Boston: Brill Styx, 2003.

Kupper, J.R. "Nahur”, RLA, 1998-2000, p.86-87.

“Nahur”. In K. Nashef (ed.) RGTC. TAVO B7/4. Wiesbaden: Dr. Ludwig Reichert, 1982, p.86.

Lecocq, P. Les Inscriptions de la Perse Achéménide. Nrf. L’aube des peuples. Sarthe: Gallimard, 1997.

Leick, G. "Column”. In A dictionary of Ancient Near Eastern Architecture I. London/US: Routledge, 2002, p.50-55.

Liverani, M. International Relations in the Ancient Near East, 16oo-11oo BC. New York: Palgrave, 2001.

Llop, J. “The development of the Middle-Assyrian provinces”, AoF 39, 2012, p. 87-111.

Meiggs, R. "The cedars of Libanon". In Trees and Timber in the Ancient Mediterranean World. Oxford: Oxford University Press, 1982, p.49-85.

Miglus, P. "Die Säule in Assyrien” in J.G. Drecksen (ed.) Assyria and Beyond, Studies presented to Mogens Trolle Larsen. Leiden: NINO, 2004, p.421-434.

Moorey, P.R.S. Ancient Mesopotamian Materials and Industries. The Archaeological Evidence. Oxford: Clarendon Press, 1994.

Munn-Rankin, J.M. "The campaigns of Adad-nirari”. In I.E.S Edwards et al. (eds) Cambridge Ancient History 2/2: History of the Middle East and the Aegean Region c.130o-10oo B.C. Cambridge: Cambridge University Press, 2008, p.274-279.

Pedde, F., and Lündstrom, S. Der Alte Palast in Assur. Architektur und Baugeschichte. WVDOG 120. Wiesbaden: Harrassowitz, 2008.

Porter, R.M. "Reused columns in the 'Stelenreihen", N.A.B.U. 4/83, 2002, p.80-81. 
Postgate, J.N. The Archive of Urad-Šerūa and His Family. A Middle-Assyrian Household in Government Service. Roma: Herder, 1988.

Trees and timber in the Assyrian texts", Bulletin on Sumerian Agriculture 6, 1992 , p.177-192.

Powell, M.A. "Masse und Gewichte”, RLA 07, 1987-90, p.457-517.

Tadmor, H. "World dominion: The expanding horizon of the Assyrian empire". In L. Milano, F.M. Fales \& G.B. Lafranchi (eds) Landscapes, Frontiers and Horizons in the Ancient Near East. CRAI 441997 V1. Invited Lectures. Padova: Sargon, 1999, p.55-62.

Weidner, E. "Säulen aus Nahur", $A f O$ 17, 1954-1956, p.145-146. 